\title{
TIGA ALIRAN PEMBAHARUAN \\ Westernisme, Islamisme dan Nasionalisme
}

Drs. Muhammad Muhtarom Ilyas

\begin{abstract}
Abstrak
Setelah mengalami kemunduran, Turki Usmani tidak henti untuk berusaha mengadakan pembaharuan-pembaharuan terutama dalam sektor perubahan pemerintahan absolut menjadi pemerintahan konstitutional. Dan inilah sebenarnya yang menjadi obyek setiap gerakan pembaharuan di kerajaan Usmani. Sedangkan bidang lainnya hanyalah merupakan konsekuensi logis dari perubahan sistem pemerintahan. Walaupun kelihatannya pada setiap tujuan utama pembaharuan itu sama, namun sesungguhnya dalam berbagai hal terdapat perbedaan. Perbedaan dapat terlihat dalam dasar pandangan, dasar pijakan dan ide pembaharuan. Dengan adanya perbedaan inilah gerakan pembaharuan di kerajaan Usmani dapat dikelompokkan kedalam tiga macam aliran: aliran barat (Westernisme), aliran Islam (Islamisme) dan aliran nasionalis (Nasionalisme).
\end{abstract}

Kata Kunci: pembaharuan, westernisme, islamisme dan nasionalisme

Kerajaan Usmani (ottoman Empire) merupakan kerajaan Islam yang mempunyai daerah territorial yang sangat luas terbentang du tiga benua: Eropa, Asia dan Afrika. Kerajaan ini, pernah mencapai puncak kejayaannya antara tahun 14811566, yaitu pada masa perintahan Sultan Bayazid II dan Sultan Sulaiman al-Qanuni. Setelah masa pemerintahan Sultan Sulaiman al-Qanuni, kerajaan Usmani diperintah oleh para Sultan yang lemah, yang tidak mempunyai perhatian terhadap masa depan bangsa dan rakyatnya, hingga rakyatnya tetap tradisional dan statis, negara makin lama makin lemah dan akhirnya mengalami kemunduran, khususnya dalam bidang ilmu pengetahuan dan teknologi.

Setelah mengalami kemunduran, usaha untuk memperbaiki kerajaan pemerintahan kerajaan Usmani pernah dirintis oleh Sultan Ahmad III (1703-1730), yang kemudian dikenal dengan istilah pembaharuan sebelum Periode Modern. (Harun Nasution, 1988). Karena mendapat tantangan dari kaum ulama' dan militer, pada akhirnya usaha pembaharuan ini mengalami kegagalan.

Usaha pembaharuan berikutnya dilaksanakan pada periode Modern, yang diawali oleh Sultan Mahmud II (1807-1839). Tercatat dalam sejarah, Sultan Mahmud II merupakan Sultan Usmani pertama yang merombak tradisi aristokrasi, 
dengan mengambil sikap demokratis. Ia juga dikenal sebagai Sultan yang pertama sekali di kerajaan Usmani yang dengan tegas mengadakan perbedaan antara urusan agama dan urusan dunia.

Usaha-usaha pembaharuan berikutnya dilakukan oleh kelompok intelektual yang dikenal dengan gerakan Tanzimat (1834-1871). Tujuan utama gerakan ini ialah mengatur, menyusun serta memperbaiki struktur organisasi pemerintahan, termasuk bidang ekonomi, pendidikan dan kebudayaan. Selanjutnya, usaha pembaharuan juga dilakukan oleh gerakan Usmani Muda dan Turki Muda. Tujuan utama dua gerakan ini adalah mengubah pemerintahan absolut kerajaan Usmani menjadi pemerintahan konstitutional. Dan inilah sebenarnya yang menjadi obyek setiap gerakan pembaharuan di kerajaan Usmani. Sedangkan bidang lainnya hanyalah merupakan konsekuensi logis dari perubahan sistem pemerintahan.

Walaupun kelihatannya tujuan utama setiap pembaharuan itu sama, yaitu terbentuknya negara konstitusional, namun sesungguhnya dalam berbagai hal terdapat perbedaan. Hal ini, dapat terlihat dalam dasar pandangan, dasar pijakan dan ide pembaharuan. Karena berbagai perbedaan ini, gerakan pembaharuan di kerajaan Usmani dapat dikelompokkan kedalam tiga macam aliran: aliran barat (Westernisme), aliran Islam (Islamisme) dan aliran nasionalis (Nasionalisme), sehingga dalam karya ilmiyah ini penulis mencoba mengkaji karakteristik aliranaliran tersebut, ide-idenya baik persamaan maupun perbedaannya serta langkahlangkah yang mereka lakukan.

\section{Westernisme}

Yang dimaksud dengan aliran ini ialah golongan/para tokoh pembaharuan yang ingin mencontoh peradaban barat sebagai dasar pembaharuan di kerajaan Usmani. (Niyazi Berkes' 1964). Aliran barat ini beranggapan bahwa dunia barat saat itu telah mencapai peradaban yang tinggi sebagai buktinya adalah bangsa barat telah mencapai keberhasilan mengembangkan ilmu pengetahuan dan teknologi. Mereka juga telah meninggalkan tradisi-tradisi lama, termasuk tradisi keagamaan yang tidak sesuai dengan perkembangan zaman. 
Dalam pandangan westernisme, jika ingin maju, kerajaan Usmani harus berkiblat pada bangsa barat serta mulai meninggalkan tradisi dan institusi-institusi lama yang telah ketinggalan zaman karena bagi mereka (westernisme) tradisi dan institusi-institusi lama-lah yang menjadi penyebab kemunduran bangsa. (Harun Nasution, 1988).

Hal ini perlu, demikian kata Tewfiq Fikret, sebab menurutnya, penyebab utama kemunduran umat Islam pada saat itu adalah karena pemikiran mereka terbelenggu oleh paham fatalisme (Satu aliran teologi yang menempatkan manusia sebagai makhluk yang tidak mempunyai kemampuan dan kebebasan untuk melakukan suatu perbuatan). Salah satu tokoh lainnya yang terkenal menonjol pemikirannya dan merupakan salah seorang pendiri Perkumpulan Persatuan dan Kemajuan (Society of Union and Progress) adalah Dr. Abdullah Jewdat. Menurutnya, kerajaan Usmani yang perlu diubah bukanlah sultan (sistem pemerintahannya) tetapi sistem sosialnya. Baginya, Kelemahan kerajaan Usmani dan umat Islam seluruhnya terletak pada kejahiliyahan, kemalasan, kepercayaan yang sangat kuat pada tahayul, juga terlalu patuh pada "ulama' bodoh" yang semuanya itu dianggap sebagai ajaran Islam.

\section{Islamisme}

Aliran pembaharuan ini merupakan lawan terkeras bagi westernisme. Aliran ini terdiri atas tiga kelompok. Kelompok pertama merupakan kelompok kecil, dan keberadaannya pun relatif singkat, kelompok ini tergabung dalam organisasi Jamiyyah Ilmiyyah al-Islamiyah yang memiliki media cetak Bayan al-Haq sebagai media untuk menentang setiap ide yang dimunculkan oleh aliran Barat. Polemik yang pernah muncul antara golongan ini dengan Barat antara lain masalah poligami dan photography, bagi golongan ini photography termasuk masalah yang membawa kekufuran.

Kelompok kedua dari Islamisme dipimpin oleh Said Nursi (1867-1960), kelompok ini menghendaki suatu penghendaki suatu pemerintahan yang memberlakukan syariat sebagi konstitusi. Mereka juga menghendaki 
diberlakukannya syariat sebagi satu-satunya hukum yang berlaku bagi seluruh rakyat, mengingat mayoritas penduduk adalah Muslim (Niyazi Berkes, 1964).

Kelompok ketiga, yang merupakan kelompok terkuat dari Islamisme adalah kelompok shirat al-Mustaqim, tokoh utama dari kelompok ini adalah Mehmed Akif (1870-1936). Sebagaimana kelompok sebelumnya, kelompok ini juga menentang keras adanya pemikiran yang akan memisahkan antara agama dan negara. Mereka juga menentang faham yang menyamakan kedudukan wanita dengan pria.

Menurut pendapat Mehmed Akif, untuk memajukan kerajaan Usmani tidak perlu mengambil kebudayaan Barat secara utuh. Dalam hal ini ia memberi contoh bangsa Jepang yang bisa maju dengan memfilter ilmu pengetahuan dan teknologi bangsa Barat saja dan meninggalkan kebudayaannya. Ia juga berpendapat, bahwa kelemahan umat Islam saat ini bukan karena agamanya. Ia menolak dengan keras pendapat yang mengatakan bahwa agama merupakan penghalang dan penghambat kemajuan (Harun Nasution, 1988).

Secara umum, Aliran Islam (Islamisme) ini dapat dikatakan sebagai suatu golongan yang menjadikan syariat sebagai titik tolak dan pedoman dalam pembaharuan. Mereka menghendaki agar syariat menjadi satu-satunya konstitusi dan hukum yang dilaksanakan secara utuh dalam negara dan diberlakukan untuk segala aspek kehidupan masyarakat. Yang dimaksud dengan syariat oleh aliran ini bukanlah ajaran Islam yang terdapat dalam al-Qur'an dan as-Sunnah, tetapi ajaran Islam yang terdapat dalam buku fiqih. Sebagaimana diungkapkan oleh Prof. Dr. Harun Nasution: ... yang mereka maksud dengan syariat, kelihatannya ialah hukum fiqih.

\section{Nasionalisme}

Aliran pembaharuan yang ketiga dan paling akhir adalah Nasionalisme. Ia lahir dari ide Nasionalis Turki yang lahir dan tumbuh dari alam Turki sendiri. Ia muncul sebagai sintesa antara kegagalan westernisasi dan Islamisasi di kerajaan Usmani (Niyazi Berkes, 1964). Bukan lagi rahasia bahwa kerajaan Turki Usmani memiliki daerah territorial yang sangat luas. Penduduknya terdiri dari berbagai macam suku bangsa, sebut saja, bangsa Turki, Arab, Eropa dan bangsa-bangsa lain. 
Permulaan aliran nasionalis ini lahir dari persamaan agama (Millet), maksudnya semua orang muslim, baik yang berkebangsaan Turki, Arab, Eropa maupun bangsa lainnya merupakan satu kelompok bangsa. Namun, setelah munculnya kesadaran nasionalisme yang dimulai oleh bangsa Eropa, kemudian diikuti oleh bangsa Arab sehingga persamaan agama tidak dapat dikatakan lagi sebagai ikatan kebangsaan. Seiring dengan itu, muncul pula pemikiran Pan Turkisme yang memiliki tujuan menyatakan seluruh orang kebangsaan Turki, baik yang berada di wilayah Turki maupun yang di luar wilayah Turki. Hal tersebut jelas akan sulit untuk dilaksanakan, karena akan mendapat perlawanan dari negara-negara lain, terutama dari Rusia. Akhirnya lahirlah pemikiran Nasionalisme yang didasarkan kepada pemikiran budaya, yakni pengelompokan orang-orang Turki yang terbatas pada wilayah kerajaan Usmani. Pemikiran kelompok inilah yang kemudian dikenal dengan sebutan kelompok Nasionalisme.

Aliran ini menjadikan nasionalisme sebagai titik tolak dalam mengadakan pembaharuan. Semua usaha pembaharuan yang mereka lakukan senantiasa dikaitkan dengan kepentingan nasional, persatuan dan kesatuan bangsa Turki. Dalam sistem pemerintahan misalnya, kelompok ini setuju dengan sistem yang diterapkan di dunia Barat termasuk kecenderungannya kepada pemerintahan sekuler. Namun demikian, mereka menolak untuk mengambil kebudayaan bangsa Barat secara utuh dan tanpa reserve. Mereka hanya memilih hal yang sesuai dan bisa dijadikan sebagai model untuk pembentukan kebudayaan nasional Turki yang modern.

Salah satu pemikiran tokoh mereka Zia Gokalp (1875-1924) yang patut dikemukakan disini adalah konsep nasionalismenya. Menurut pendapatnya nasionalisme didasarkan bukan atas bangsa (rase), sebagaimana dianut oleh paham Pan-Turkisme, tetapi atas kebudayaan. Menurutnya, kebudayaan dan peradabadan sama sekali berbeda. Kebudayaan Turki kerajaan Usmani dengan kebudayaan Turki Rusia terdapat perbedaan. Dengan demikian, baginya Turki kerajaan Usmani merupakan satu unit nasional tersendiri dan Turki Rusia begitu pula merupakan satu unit nasional tersendiri (Harun Nasution). Kebudayaan adalah hal yang unik, nasional, sederhana, subyektif dan timbul dengan sendirinya. Sedang peradaban 
bersifat umum, internasional, obyektif dan diciptakan. Kebudayaanlah yng membedakan satu bangsa dengan bangsa yang lain (Taufiqurrahman, 2009).

\section{Ide Pembaharuan}

Pembaharuan yang telah dilakukan semenjak Sultan Mahmud II, merupakan pembaharuan yang lebih melihat pada Barat menjadi ide utamanya yang pada akhirnya membawa akibat pada pengadopsian besar-besaran terhadap segala perangkat hukum, politik, ekonomi, pendidikan Barat untuk diterapkan di kerajaan Usmani. Inilah yang akhirnya menumbuh suburkan Westernisme di Turki. Timbulnya Westernisme itu sendiri karena negara Islam tidak lagi dipandang mempunyai kelebihan dan masyarakatnya telah menutup sejarah masa lalu. Maka mengadopsi unsur Barat menjadi satu-satunya jalan untuk mencapai kemajuan dan kemakmuran dalam peradaban yang adiluhung.

Tuefik Fikret dan Abdullah Cevdet sebagai pengusung westernisme memandang bahwasannya westernisme adalah transformasi mental secara menyeluruh melalu proses membuang sistem yang lama dan menggantinya dengan sistem Barat. Pandangan westernisme tersebut antara lain : pertama, penyebab kemunduran Turki karena pikiran Asia, lembaga dan tradisinya lemah begitu juga moral dan mentalnya. Kelemahan mental dan moral tersebut disebabkan oleh syari'at yang menguasai seluruh kehidupan bangsa Turki. Obatnya adalah tradisi barat, dengan memisahkan negara dari otoritas agama, dalam artian agama-agama yang telah rusak oleh zaman dan bukan ajaran Islam yang asli dan rasional. Meskipun begitu mereka dapat dikatakan masih concern pada Islam. Kedua, pembaharuan keagamaan yaitu menentang kefanatikan Ulama' Turki yang tradisional, yang dianggap sebagai sumber kemunduran, memasukkan ilmu pengetahuan modern sehingga dapat menghasilkan Ulama' yang berpandangan modern, menekankan ajaran agama pada kehidupan duniawi dan mengusahakan penerjemahan al-Qur'an ke dalam bahasa Turki. Ketiga, pembaharuan ekonomi, menjadikan sistem perekonomian Barat sebagai sistem ekonomi Turki, seperti kapitalisme, individualisme, liberalisme, dan bekerja untuk menumpuk harta. Kemunduran Turki disebabkan karena masyarakat Turki berpegang pada tradisi dan 
institusi yang dipengaruhi oleh faham fatalisme. Keempat, Pembaharuan lembaga negara, dengan memisahkan otoritas negara dari otoritas agama. Kelima, pembaharuan pada keluarga, dimana kemunduran Turki disebabkan oleh status dan kedudukan wanita sangat rendah. Untuk memajukan Turki, wanita harus diangkat derajatnya sejajar dengan pria, menghapus sistem poligami, pelepasan kerudung wanita. Keenam, Pembaharuan pendidikan yaitu memberikan muatan kurikulum ilmu pengetahuan modern di segala jenis dan jenjang pendidikan. Pengajaran agama dijatuhkan dari takhayyul dan menekankan keduniaan lebih besar dibanding keakhiratan.

Pemikiran tokoh westernisme Turki di atas mendapat reaksi keras dari golongan Islam dengan tokoh diantaranya adalah Mehmed Akif dan Musa Kazim. Pemikiran tokoh-tokoh Islam tersebut adalah pertama, kemunduran Turki bukan disebabkan Islam atau pengaruh syari'at tapi justru karena syari'at tidak diterapkan kesultanan Usmani. Obatnya adalah menerapkan syari'at yang mencakup seluruh kehidupan rakyat. Argumentasi ini didukung oleh realitas sejarah dimana meski telah melakukan pembaharuan Turki tetap lemah. Jepang maju bukan merubah sistem budayanya tapi hanya mengambil perangkat teknologi dari Barat. Kedua, pembaharuan di bidang agama tidak banyak terlihat karena mereka lebih menginginkan penerapan syari'at Islam sesempurna mungkin dan tetap mempertahankan institusi yang ada. Ketiga, dalam bidang ekonomi mereka setuju ada pembangunan ekonomi untuk tercapainya kesejahteraan. Mereka menentang ide kapitalisme, individualisme, liberalisme, sosialisme, dan komunisme Barat. Bagi mereka kemajuan ekonomi bisa dikembangkan tanpa mengorbankan prinsip agama. Keempat, bidang kenegaraan, mereka tidak puas dengan konstitusi 1876 karena dalam pelaksanaannya hukum Islam belum diterapkan secara penuh, meski dasar negaranya Islam. Soal membuat undang-undang adalah hak Tuhan, dimana Ulama' mempunyai wewenang menginterpretasikannya. Dengan demikian Ulama' mempunyai hak mengatur negara dimana pelaksanaannya berwujud raja yang berfungsi khalifah sebagai pimpinan agama dan Sultan berfungsi sebagai pimpinan pemerintahan. Kelima, mereka menentang pandangan Barat tentang wanita. Melepaskan kerudung bukanlah mengangkat derajat wanita, tapi justru menghina 
dan menyebabkan dekadensi moral. Wanita tidak diberi hak dalam masalah cerai karena wanita lebih emosional. Keenam, dalam pendidikan, mereka mendukung masuknya ilmu-ilmu modern dan yang mereka tentang adalah penanaman nilai sekuler. Madrasah tetap dipertahankan untuk memberikan porsi pendidikan agama lebih banyak (Taufiqurrahman, 2009).

Pemikiran kelompok nasionalisme dikembangkan oleh Ziya Gokalp dan Yusuf Ackura. Mereka mencoba menggabungkan kecenderungan pemikiran westernisme dan Islamisme yang diangkat sebagai sintesa, meskipun agak berbeda karena prinsipnya berbeda. Pandangan pembaharuan nasionalisme antara lain pertama, kemunduran Turki disebabkan karena ketidakmampuan mereka menerima perubahan dan melakukan interpretasi baru ajaran Islam sesuai dengan kondisi sosialnya. Sebab lain adalah hilangnya budaya Turki karena terdesak oleh peradaban Islam. Obatnya adalah menghilangkan institusi tradisional usang yang telah diciptakan peradaban Islam. Namun ketika mau membangun peradaban, nilai Islam harus tetap menjadi jiwanya, budaya Barat hanya menjadi model kebudayaan nasional Turki. Pembaharuan Turki bukan berdasarkan syari'at, bukan kebudayaan Turki sebelum Islam atau Barat, tapi kebudayaan nasional Turki modern. Kedua, dalam agama mereka menginginkan pemisahan antara diniyet dan muamilet. Hukum ibadah atau diniyet merupakan urusan Ulama', sedang muamalah menjadi urusan negara. Inilah yang disebut pemisahan negara dan agama. Kekuasaan legislatif yang selama ini berada pada Syekh al Islam dikembalikan pada parlemen, begitu juga mahkamah syari'ah dipindah ke kementerian Kehakiman. Madrasah dikelola oleh kementerian Wakaf. Ketiga, bidang ekonomi, kelompok ini menyerang kelompok Islam yang menyamakan bunga uang dengan riba, bagi mereka bunga adalah hasil transaksi sewa menyewa. Keempat, lembaga negara, mereka setuju dengan pendapat kelompok Barat tentang pemisahan kelompok agama dan kekuasaan politik negara. Kelima, tentang wanita, mereka mengusulkan persamaan status wanita dan pria dalam bidang pendidikan, perkawinan pewarisan dan poligami dihapus. Keenam, dalam pendidikan, mereka setuju dengan pandangan kelompok Islam bahwa Turki sedang mengalami krisis moral akibat melemahnya pengaruh nilai-nilai agama, namun solusinya bukan memberikan pendidikan agama karena masyarakat Turki 
sudah berubah dari masyarakat agama menuju masyarakat nasional. Dalam pendidikan harus diterapkan nilai moralitas sekuler. Madrasah, maktab, sekolah asing tidak menciptakan kreatifitas baru tapi merupakan tiruan kebudayaan asing dan bukan merupakan kebudayaan Turki.

Pertentangan antara ketiga kelompok ini pada akhirnya dimenangkan oleh kelompok nasionalis dengan terbentuknya negara nasional Turki modern. Turki menjadi negara dengan bentuk republik dipimpin oleh Mustofa Kemal Ataturk yang diproklamirkan pada tanggal 29 Oktober 1923. Pembentukan negara Turki pada gilirannya menghapus institusi kekhalifahan (1924), serta mengakhiri dominasi Ulama' dan akhirnya menjadi negara sekuler. Turki dengan undangan-undangan tahun 1937 menegaskan diri sebagai negara Turki dengan bentuk republik, nasional, kerakyatan, kenegaraan, sekularis dan revolusioner. Dan yang menjadi penjaga dan pengawas konstitusinya sampai saat ini adalah militer (Taufiqurrahman, 2009).

\section{Daftar Pustaka}

Nasution, Harun. 1988. Pembaharuan dalam Islam, Sejarah Pemikiran dan Gerakan. Jakarta: Bulan Bintang.

Niyazi Berkes, 1964. The Development of Secularism in Turkey. Montreal: McGill University Press.

Syadzali, Munawir. 1992. Islam dan Tata Negara, Ajaran, Sejarah dan Pemikiran. Jakarta, UI Prees.

Taufiqurrahman, 2003. Sejarah Sosial Masyarakat Islam. Surabaya: Pustaka Islamika.

Dian Ilmu.

Waliyullah, Syah. 1964. Hujjatul al-Balighah, Kairo, Darul Kutub Hadibiyah. 